tion, which concerns the vane itself, and not the registration of its movements; and in justice to the signal office it ought to be said that a method of registration precisely similar to Dr. Draper's has been in use for many years. Indeed, it is through the study of the records made by this method that the imperfections of the vane are made to appear.

Terre Haute, April 11.

T. C. M.

\section{The power of a voter.}

In the general election of 1884 the total number of votes cast in the country was $10,048,061$. The number of senators is 76, and the number of representatives is 325 . With these numbers, and the total vote of each state in this election, the following table has been computed, in which the figures of the columns give the relative power of votes in the different states :-

\begin{tabular}{|c|c|c|c|}
\hline & $\begin{array}{c}\text { Senatorial } \\
\text { power. }\end{array}$ & $\begin{array}{c}\text { Representa- } \\
\text { tive } \\
\text { power. }\end{array}$ & $\begin{array}{c}\text { Presidential } \\
\text { power. }\end{array}$ \\
\hline Alabama........... & 86 & 52 & 65 \\
\hline Arkansas.............. & 105 & 40 & 56 \\
\hline 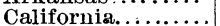 & 68 & 31 & 41 \\
\hline Colorado.............. & 199 & 15 & 45 \\
\hline Connecticut......... & 96 & 29 & 44 \\
\hline Delaware.......... & 439 & 33 & 100 \\
\hline Florida.............. & 221 & 33 & 67 \\
\hline Georgia............ & 92 & 70 & 84 \\
\hline Illinois............. & 20 & 30 & 33 \\
\hline 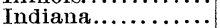 & $\tilde{2}^{\prime \prime}$ & 26 & 30 \\
\hline Iowa................. & 35 & 29 & 35 \\
\hline 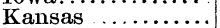 & 50 & $\tilde{2} 6$ & 34 \\
\hline Kentucky............. & 48 & 40 & $\begin{array}{l}04 \\
47\end{array}$ \\
\hline Louisiana......... & 121 & 55 & 73 \\
\hline Maine.............. & 102 & 31 & 46 \\
\hline 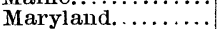 & 71 & 32 & 43 \\
\hline Massachusetts..... & 44 & 40 & 46 \\
\hline Michigan.......... & 33 & 27 & 32 \\
\hline Minnesota............ & 70 & 26 & 37 \\
\hline Mississippi........ & 110 & 58 & 75 \\
\hline 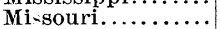 & 30 & 32 & 36 \\
\hline Nebraska.............. & 98 & 22 & 37 \\
\hline 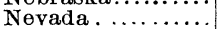 & 1,033 & 78 & 234 \\
\hline New Hampshire... & 156 & 24 & 47 \\
\hline New Jersey........ & 51 & $2 t$ & 34 \\
\hline New York ............... & 11 & 29 & 31 \\
\hline North Carolina.... & 49 & 34 & 41 \\
\hline Ohio. ........... & 17 & 27 & 29 \\
\hline Oregon & 251 & $\tilde{19}$ & 57 \\
\hline Pennsylvania ...... & 15 & 30 & 32 \\
\hline Rhode Island... . & 403 & 61 & 122 \\
\hline South Carolina.... & 144 & 76 & 98 \\
\hline Tennessee ......... & 51 & 38 & 46 \\
\hline Texas.............. & 41 & 34 & 40 \\
\hline Vermont........... & 223 & 34 & 67 \\
\hline Virginia................ & 46 & 35 & 42 \\
\hline West Virginia...... & 100 & 30 & 45 \\
\hline Wisconsin.......... & 41 & 28 & 34 \\
\hline
\end{tabular}

In many of the states the conditions are such that a full vote is rarely polled. The smallest percentage of voters to males over twenty-one years was in Rhode Island, where it was less than 43 per cent. In Massachusetts and Mississippi the percentage was about 60 . In Florida it was more than 90 per cent. Notwithstanding this defect, the table shows very well how political power is distributed among the voters with respect to the legislative and executive branches of the general government. It will be seen that the distribution of this power is much more uniform in the house of representatives, as was intended; and this fact will evidently be a source of power to this house in its conflicts with the other branch of the legislature. On the other hand, the difference of the senatorial power of voters in the states has become very marked. Thus a single voter in the state of Nevada has as much senatorial power as 91 voters in New York; and a voter in Delaware, 39 times as much as one in New York, and 9 times as much as one in Kentucky. The New England states have more than 9 times the power of New York. In addition to this, in some of the states the senators are elected by a minority of the voters. Where political power is so unequally divided, the respect for the legislative body will depend largely on its wisdom, and the fairness of its conduct towards the whole country. But it is doubtful whether such a condition is peimanent. Asaph Hall.

Washington, April 4.

\section{On tiptoe.}

Allow me to say a few final words. The fulcrum of a lever is that axis of rotation with reference to which an equation of moments, consistent with the principle of work, can be stated. It is my belief that the ankle is the fulcrum of the foot under the circunistances of the problem before us.

How can Professor LeConte's equation be correct as it stands, $P \times C A=I V \times C B+P \times C B$, unless the traverse of $P$ be the distance 'virtually' moved

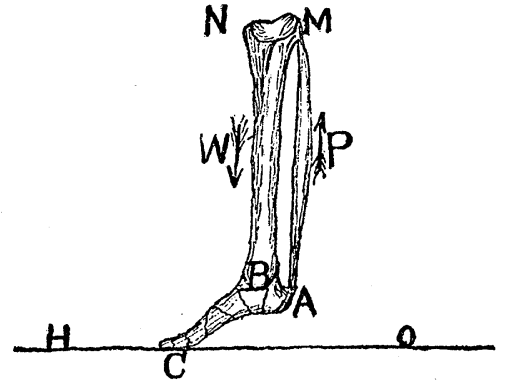

over by the point $A$ of his figure? I claim to have proved that the traverse of $P$ is not that distance, but that the arm of $P$ is $B A$, if the arm of $W$ be $C B$. If the toe must be the fulcrum, a proper equation of moments may be stated by regarding the case as of the third order, with power 'virtually' applied at a distance from toe equal to the distance between heel and ankle. On this view, a foot might be constructed which could be regarded as of the second order, by putting ankle nearer to toe than to heel, or an indeterminate case could occur if ankle were midway between toe and heel. Why not proceed as in the case of the Roberval balance, for instance, by tracing the pressures, produced by bodies applied to the system, to the axes of rotation where such pressures become effective as 'power' and 'resistance'?

Finally, I regard the case under discussion as of the first order, because, first, no proper equation of moments seems possible with power at heel and fulcrum at toe; secondly, a 'virtual' axis must be assumed with power at ankle and fulcrum at toe; thirdly, with power at heel and fulcrum at ankle, the conditions are as usual, except that the mutua! ten. dency of the earth and the 'weight' to approach, vach other - which tendency produces the 'resist. ance' - is exerted by the earth at the end of the lever and by the weight at the fulcrum, instead cf vice versa. F. C. VAN DYCK.

New Brunswick, N.J., April 9. 